\title{
Pattern of Elderly Living Arrangement in Asia
}

\section{Nurul Raffiza Norzehan, Nik Norliati Fitri Md Nor, \& Suriati Ghazali}

To Link this Article: http://dx.doi.org/10.6007/IJARBSS/v11-i5/9744

DOI:10.6007/IJARBSS/v11-i5/9744

Received: 24 March 2021, Revised: 27 April 2021, Accepted: 11 May 2021

Published Online: 19 May 2021

In-Text Citation: (Norzehan et al., 2021)

To Cite this Article: Norzehan, N. R., Nor, N. N. F. M., \& Ghazali, S. (2021). Pattern of Elderly Living Arrangement in Asia. International Journal of Academic Research in Business and Social Sciences, 11(5), 319-335.

\section{Copyright: (c) 2021 The Author(s)}

Published by Human Resource Management Academic Research Society (www.hrmars.com)

This article is published under the Creative Commons Attribution (CC BY 4.0) license. Anyone may reproduce, distribute, translate and create derivative works of this article (for both commercial and non-commercial purposes), subject to full attribution to the original publication and authors. The full terms of this license may be seen at: http://creativecommons.org/licences/by/4.0/legalcode

\section{Vol. 11, No. 5, 2021, Pg. 319 - 335}

Full Terms \& Conditions of access and use can be found at http://hrmars.com/index.php/pages/detail/publication-ethics 


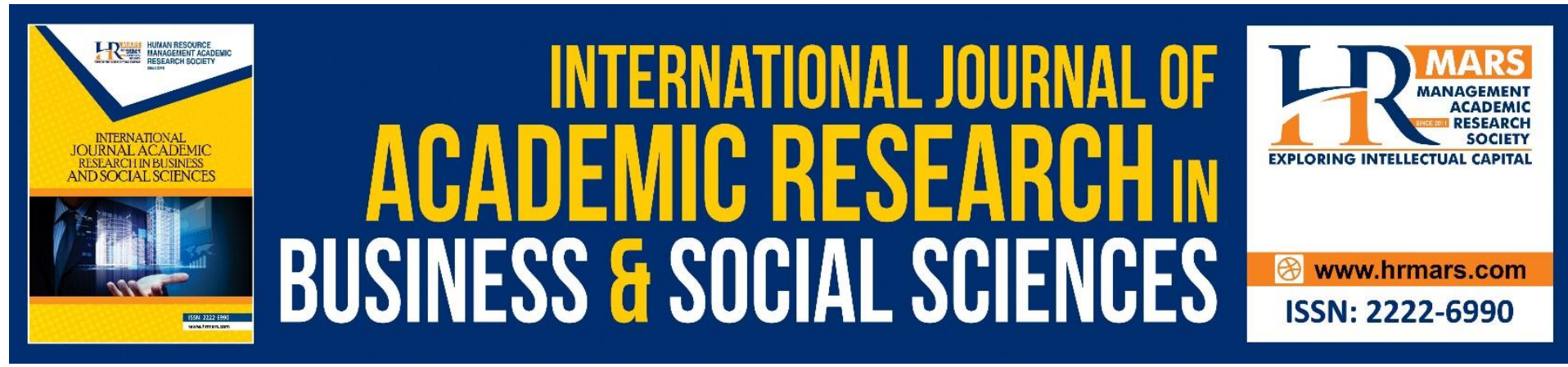

\title{
Pattern of Elderly Living Arrangement in Asia
}

\author{
${ }^{1}$ Nurul Raffiza Norzehan, Nik Norliati Fitri Md Nor, \& ${ }^{2}$ Suriati \\ Ghazali \\ ${ }^{1}$ Geography Section, School of Distance Education, ${ }^{2}$ Geography Section, School of \\ Humanities Universiti Sains Malaysia, 11800 Penang, Malaysia \\ Email: nikfitri@usm.my
}

\begin{abstract}
Changes in Asian household composition indicated that proportion of elderly are not living with their children and the proportion of 'living alone' has become an increasing pattern of living arrangements. This concept paper will gauge on factors associated with pattern of living arrangement preferred by Asian elderly based on ten existing research studies collected from secondary sources such as Google Scholars and Research Gate from year 2010- 2020 for literature review analysis of pattern of elderly living arrangements. The study reveals that elderly living arrangements in Asia is predominantly to live with children due to Asian cultural values embedded. However, 'living alone' shows an increasing trend which associated with factors like socioeconomic background, abusive experience, income, health issues, privacy and freedom. This study highlight on role of society in willingness to provide for the elderly that lives alone with poor financial conditions. Government should upgrade their policy on financial assistance that helps elderly enjoy their later life with better policy of societal aging. Keywords: Pattern, Elderly, Living Arrangements, Asia, Children
\end{abstract}

\section{Introduction}

Asian countries has always been identified with strong culture value in the world that uphold its traditions of family values. However, the recent increasing trend of elderly abandonment is showing an alarming numbers of elderly being abandon especially in terms of their living arrangements. This has awakened a question if the Asian household values is still applicable in modern era especially involving the elderly living arrangements. There are many studies looked into different demographic of Asia that focuses on elderly studies that associate family relationship influence elderly living arrangement pattern. However, rarely realized by community is that there is an increasing pattern of elderly living alone instead of sharing the household with family or with relatives of other generations due to preference for privacy and freedom. Although globally Asian countries still ranked as the lowest older person living alone type of living arrangements with only below 1 per cent but some countries shows an increasing pattern as per study conducted by Kamiya \& Hertog (2020). Thus, it is vital for adult children and society to understand and acknowledge that elderly has the rights to determine on how and where their living arrangements supposed to be as it is one of their fundamental rights under human rights law (Fredvang \& Biggs, 2012). Sometimes elderly living arrangements that is considered ideal by their adult children is not what the elderly needs 
and preferred. Must be remembered that, some elderly that chose to live the family or relatives are not excluded from worrisome or a threatening life and eventually opt for different type of living arrangements (living alone, living in an institutional care, co-residence with stranger and etc). There are considerable variations to each elders that majority of them are realizing the importance of living separately which will not be discussed in this paper. This paper focuses on analysing existing articles that has been chosen from Google scholars and Research Gate in depth of pattern of elderly living arrangements in Asia. The discussion on pattern of elderly living arrangements in Asia is pertinent as it contributes towards global efforts to achieve sustainable development goals amongst the elderly (especially in poverty, hunger, and health) in scholarly spectrum.

\section{Statement of Problem}

This special collection consists of ten articles that examines the pattern of elderly living arrangements in Asia. This paper summarizes their findings, highlights the factors that associated with pattern of elderly living arrangements in Asia well- being.

\section{Value of Study}

This research paper will be guided by the following objectives:

1) To find out the pattern of elderly living arrangements in Asian countries

2) To determine the factors that associated with preferred/ chosen elderly living arrangements

\section{Analysis of Literature Review}

General idea of a family unit in Asia is a stable organized involving around parent and children. However, recently there are many analysed trends in family breakdowns that have challenged the notion that the demise of the household unit is relatively due to modernization. A healthy living arrangement in a senior age is essential for elderly for them to feel a greater sense of freedom and self-expression (Laramie, 2020). Elderly are tend to rely on their family and friends for a community support and to have companionship and their willingness to accept assistance influence the choice of elderly living arrangements.

Agrawal (2012) discuss on association between lack or inadequate family support with increased mortality and poor health among the elderly in India. Common health issue found amongst Indian elderly are asthma, tuberculosis, malaria, and jaundice. Agrawal examine the effect of living arrangements on common found diseases on Indian elderly and stressed that elderly that lives alone are 1.5 times possible in suffering from asthma compared to them who lives with family. For TB the percentage shows two time higher for those who lives alone in comparison to those who lives with family. Whilst malaria shows 2.8 times higher in elderly that lives alone than elderly living with family. Whereas for jaundice it shows 3 times higher amongst elderly lives alone compared to them who lives with family. It is important for the Indian government policy in curbing this issue, therefore stronger public policy support is needed for those elderly that belong to weaker sections of society (lower caste/ tribe), the government policy should be inclusive in order to protect sustain the elderly living arrangements that led to healthier life.

Meanwhile, Tannistha et al. (2014) explores on association between the multigenerational household context and health of older adults in India. Multigenerational is context that has been rooted in Indian society that helped the elderly aged gracefully where they acquire sufficient support from the family members especially in term of financial 
assistance. Family support is seen as one form of capital support for the elderly in their older age especially when there is special care involved such as health issues in particular elder of the household is experiencing. Thus living arrangements is associated with illness among elderly in this paper. The paper suggested that multigenerational household contributes towards the wellness of greater health upon elderly in India. Tannistha's findings are supported by previous study by Chen \& Liu (2012), whom suggested that intra-family support led to better health and healthier lifestyles. This article finding is also supported by Chen \& Short's (2008) previous work, claiming that living with family is associated with less health disadvantage.

In addition, a study by Hadi Kooshiar et al (2012) is discussing association between different types of living arrangements and life satisfaction in older Malaysians, while taking into account the mediating effects of social support function. The result shows that elderly that lives alone has lower life satisfaction compared to elderly lives in other types of living arrangements. This article is supported by similar findings of Yah (2004), Borg (2006), and Shin (2012) who found that there is similarity of association between lower lives satisfactions inclined with living alone. Besides, this paper finding also in coherent with Ng and Lee (2002) outcomes that indicates higher life satisfaction for older adults who lived with their children compared to elderly living alone in term of social support and highlighted that social support thus related to greater life satisfaction. This scenario of elderly living with family is mainstream in Asian region and Malaysia is also deemed to have this type of living arrangement which most commonly can be found in peninsular Malaysia. It is a form standard living for the elderly to live with children due it social relationship norms. Social support from family is a crucial indicator for highly satisfaction living arrangement.

Abalos \& Barona (2013) examine on how various changes impact on the family and household by examining the living arrangements of older persons in five Southeast Asian countries: Cambodia, Malaysia, Philippines, Thailand and Vietnam. Based on census data used in this paper from Minnesota Population Center, Integrated Public Use Microdata Series (IPUMS), the author found that there is a high proportion of elder women living alone compared to male elderly and this gender gap is addressed in Malaysia and Vietnam. These two countries indicate there is trend of living alone for women. However, the study mentioned that living in extended household is still deemed to be predominant type of living arrangements. Also to be noticed in this study is that gender preferences in proportion living in extended family shows women are much more inclined to live with family compared to men and equal to that women also choosing the living arrangement as a nuclear household. Although there is gender differences in preference of type of living arrangement, these Asian countries are still predominantly maintaining living in extended households.

Jiehua \& Yun (2017) examine the changes and consequences of the patterns of Chinese elderly population's living arrangements. From 2000-2010 marked the patterns and trends of living arrangements among Chinese elderly focusing on dynamic changes of living arrangements of the Chinese elderly. There are two aspects highlighted; 1) size and structure of household have reduced and 2) trend of elderly people's living arrangement has reformed. Secondly the paper focuses on household size and structure where it indicates China's one generation households has increased from 21.70 to 34.78 percent. Third focus is on elderly people within household. Above 50 percent of households with aged 65 years old and above has opted for 'live alone' as a living arrangements. The implications of changes and trends in the elderly people living arrangements are illustrated that there are large portion of elderly people in rural regions that living with adult relatives in comparison to urbanites where the 
elderly preferably living with spouse however due to urbanization the elderly living with adult relatives in rural regions shows apparent changes compared to the latter situation. Urbanization indeed has influenced the pattern 'living alone' living arrangements.

Golandaj et al (2013) studied the pattern of living arrangements among the older population and perception about old age support in the Indian adult population. This paper is gauging about useful old age support in the perspective of present generation about their preferences of old age support that helps to mould the future policies for the current and upcoming older generation. Data based India Human Development Survey (IHDS) indicates that majority older population living arrangement currently is living with extended family, 90 percent of the surveyed group are 80 above and lives with family meanwhile remaining percentage is age group of 60-69-year-old live with their spouse only. Categorized by religion, Muslims elderly are more likely to live in extended family followed by Hindu and other minority religion. It is found that more of 3.8 percent elderly women living alone compared to men only 1.1 percent. In terms of economic dimension, extended family elderly women are highly inclined toward living with son compared to the elderly living in nuclear family, as they expect son to aid them financially. The study concluded that filial responsibility has been embodied in their values and culture, although modernization does have influence on the pattern of living arrangement of the elderly, however it is not significant and these findings support that joint family system are still fostered in India.

On the contrary, elderly pattern of living arrangement does not wholly depends on familial support, but other factors associated with their preferment of living pattern arrangements. Elder people desire to maintain their independence. According to Nishanthu \& Sampath (2017) explore socioeconomic condition and living arrangement of elderly based on gender representation male and female. The result found that income factor is considered pertinent during old age because it has direct impact on living arrangements. For example housing ownership in India usually bias toward male gender indicates male chauvinism in the community despite age and status of elder women. The property rights are still denied for women in India. However, the living arrangement of elderly in this study showed positive environment that $86.31 \%$ parents are living separately from their children, indicates they have separate living space with proper infrastructure. This setting is based on nuclear family and it shows that elders belongs to nuclear family enjoy better living arrangements compared to the elders in joint family.

Different from above, Ahmed Mohammad Munsur et al (2010) paper studies on gender perspective of elderly women of Bangladesh aged 60 years and above focusing on living arrangements, health status, and abuse of the elderly women. Age group of 70-79 years has $50 \%$ of elder women living alone, women aged 80 years above has $10 \%$ less than percentage of age group 60-69 years old elderly women living alone. Elder women who are economically independent are found to be living alone compared to economically dependent elder women who supported by family members. Large amount of elderly women who has been abused significantly lives alone in order to keep away from internal family conflicts. Elderly women that belongs to higher age group are reported to be unhealthy indicates that health complications increase with aging factor. This paper defined physical abuse upon elderly women as a harm caused by someone whom they trusted or have control over them in terms of physical, psychological, and economic conditions. The perpetrator usually will be someone related to the elders such as family members. This paper concluded that elderly women condition Bangladesh is at disadvantaged due to lack of familial support thus there is a need for the country in encouraging kinship in family that lead to strengthening of joint 
family traditions. Besides, elder care centre should also be established in order to provide proper care and social support towards the elderly women.

Whereas, Wei-Jun \& Cheung (2015) summarized 10 collection of articles examining the living alone phenomena in Asia and highlights unique features found in Asia and its implications for individual well-being and societies. One-person household Asia is common trend in Asian community especially amongst elderly who lives alone. However, there is pattern in living arrangements of elderly that actually living nearby to their children in Asian countries like Myanmar, and Thailand, according to this paper the author argues that living alone is not associated with loneliness, financial constraints, and lack of family support but living independently actually makes older adults to be more socially active because they are not bound with personal commitments. Whereas, a study conducted in Singapore proven that elderly that lives alone indeed are more inclined to feel lonely however it is not a direct contributor for mortality risk. Similarly, in Korea, elderly do lives alone and this paper examined on policy changes that influence propensity of elderly and found that public are involved in assisting elderly widowed in Korea. It also highlighted that elderly with constrained financial assistance are better off to live alone while the government must assist them with welfare and lending support and treat them as a member of the society.

Racelis et al (2012) examines Filipino elderly living arrangements and other factors that may influence elderly participation in work activities that will allow the elderly to finance their expenditure for future years. Elderly working in older age shows that the percentage of working elderly will decline in accordance to their age, for example the study shows that age group of 58-64 has 65 percent while 80 years above has only 16 percent and majority of 60 percent working elderly are self-employed or they own their business. Whereas in public and private sector due to mandatory retirement at age 65 years has only 21 percent. Employment of elderly workers does determine by education factor in which it is noticeable that elderly that receive higher education are employed in a formal sector with lower illness percentage. Meanwhile self- employed elderly are engaged in home based entrepreneurial activity. Elderly living arrangements can be financed with source of income via elderly participating in work activity for their future consumption. This gives financial liberty to the elderly in order to determine how their health and well-being supposed to be taken care of and it open pathway for elderly to be more active in working environment as well as it includes promoting elderly welfare in work space. Lastly, working elderly will have a greater support in the future where it stimulates elderly employment promotion towards increasing elderly aggregate labour income.

\section{Research Hypothesis}

HO. Lack of family support is the reason for elderly to settle for 'living alone' living arrangements

H1. Family support is not the major reason for elderly to settle for 'living alone' living arrangements.

\section{Research Methodology}

\section{Research design}

This paper will be a descriptive study analysing factors that leads to patterns of elderly living arrangements in Asia. The paper is focused on familial support and other factors that mould the preference of elderly to choose the type of living arrangements they wanted.

\section{Data Collection}


This special collection consists of ten articles that examines the pattern of elderly living arrangements in Asia. The articles has been gauged thoroughly for this concept paper purpose according to family related factor and other factors that will be discussed in analysis of literature review. The ten articles used is collected from secondary sources available online mean such as Google scholar and Research Gate from year 2010 to 2020.

\section{Conclusion}

Based on analysis above, many studies found that Asian elderly pattern of living arrangements are still living with family members. Their preferences to live with children generated within the context of prevailing cultural norms of Asian family values therefore living with family members is still considered as main choice for them. Equally arising is 'living alone' pattern of living arrangements which is driven by multiple factors like socioeconomic background, abusive experience, income, health issues, privacy and freedom and etcetera are moulding the elderly choice in living arrangements as they wanted. This paper only analyse on factor contributor, this, it suggest future researcher to study widely on boon and bane of the pattern of elderly living arrangements that they choose for themselves. This study would like to highlight on role of society in willingness to provide for the elderly that lives alone with poor financial conditions. It is vital for government to upgrade their policy not only in terms of elderly labour income or pensions but also in terms of financial assistance that could allow elderly from all background enjoy their living arrangements preferences by better policy of societal aging.

\section{Acknowledgement}

The author would like to thank Universiti Sains Malaysia for funding this project through Short Term Grant (304/PJJAUH/6315265).

\section{References}

Abalos, J. B., \& Barona, M. F. C. T. (2013). "Living arrangements of older persons in Southeast Asia: Trends, pattern and determinants". International Union for the Scientific Study Population. 1-5.

Agrawal, S. (2012). "Effect of living arrangements on the health status of elderly in India". Asian Population Studies. 87-101.

Fredvang, M., \& Biggs, S. (2012). "The rights of older person, protection and gaps under human rights law". Social Policy Working Paper no.16. 1-21.

Golandaj, J. A., Goli, S., \& Das, K. C. (2013). "Living arrangements among older population and perceptions on old age assistance among adult population in India". International Journal of Sociology and Social Policy. 367-379.

Jiehua, L., \& Yun, Z. (2017). "Patterns of living arrangements of the elderly in mainland China: Changes, consequences and policy implications". Asian Education and Development Studies. 179-191.

Kamiya, Y., \& Hertog, S. (2020). Measuring household and living arrangements of older persons around the world: The United Nations database on the household and Living Arrangements of Older Persons 2019. United Nations, Department of Economics and Social Affairs, Population Division. 1-46.

Laramie, K. (2020). Veteran Care Coordination. Golden years: How seniors can live their life in 2020. https://www.vcchc.com/golden-years-how-seniors-can-live-their-best-life-in2020/ 
Nishanthu, R., \& Sampath, K. S. (2017). "Living arrangement patterns of the elderly in West Tirucirapalli, Tamilnadu, India". International Research Journal of Social Sciences. 7-11.

Racelis, R. H., Abrigo, M. R. M., \& Salas, J. M. I. S. (2012). "Filipino elderly living arrangements, work activity, and labor income as old-age support". PIDS Discussion Paper Series. 1-24.

Tannistha, S., Chen, F., \& Vanneman, R. (2014). "Living arrangement and health of older adults in India". Journal of Gerontology: Social Sciences. 937-947.

Wei-Jun, J. Y., \& Cheung, A. K. L. (2015). "Living alone: One-person household in Asia". Demographic Research. 1099-1112. 


\section{Tabular Form}

\begin{tabular}{|c|c|c|c|c|c|c|}
\hline YEAR & AUTHOR & $\begin{array}{l}\text { COUNT } \\
\text { RY }\end{array}$ & OBJECTIVE & DATA & $\begin{array}{l}\text { METHODOL } \\
\text { OGY }\end{array}$ & RESULTS \\
\hline $\begin{array}{r}1 . \\
2 \\
0 \\
1 \\
2\end{array}$ & $\begin{array}{l}\text { Agrawal, } \\
\text { S. }\end{array}$ & India & $\begin{array}{l}\text { Examine the } \\
\text { effect of } \\
\text { living } \\
\text { arrangement } \\
\text { on elderly } \\
\text { health } \\
\text { status. }\end{array}$ & $\begin{array}{l}\text { Data of } \\
39,694 \\
\text { persons } \\
\text { aged } 60 \\
\text { and above } \\
\text { included in } \\
\text { India's } \\
\text { second } \\
\text { National } \\
\text { Family } \\
\text { Health } \\
\text { Survey } \\
\text { (NFSH 2) } \\
\text { conducted } \\
\text { in } 1998- \\
1999 .\end{array}$ & $\begin{array}{l}\text { NFHS-2 is a } \\
\text { cross- } \\
\text { sectional, } \\
\text { nation-wide } \\
\text { survey, } \\
\text { which } \\
\text { collected } \\
\text { demographi } \\
\text { c, } \\
\text { socioecono } \\
\text { mic } \\
\text { and health } \\
\text { information } \\
\text { from a } \\
\text { nationally } \\
\text { representat } \\
\text { ive } \\
\text { probability } \\
\text { sample of } \\
\text { 92,486 } \\
\text { households. } \\
\text { Details of } \\
\text { sample } \\
\text { design, } \\
\text { including } \\
\text { sampling } \\
\text { framework } \\
\text { and sample } \\
\text { implementa } \\
\text { tion, are } \\
\text { provided in } \\
\text { the basic } \\
\text { survey } \\
\text { report for } \\
\text { all India } \\
\text { (Internation } \\
\text { al Institute } \\
\text { for } \\
\text { Population } \\
\text { Sciences \& } \\
\text { ORC Macro } \\
\text { 2000). The } \\
\text { household }\end{array}$ & $\begin{array}{l}\text { Results } \\
\text { indicate that } \\
\text { elderly who } \\
\text { are living } \\
\text { alone are } \\
\text { likely to } \\
\text { suffer more } \\
\text { from both } \\
\text { chronic } \\
\text { illnesses, } \\
\text { such as } \\
\text { asthma and } \\
\text { tuberculosis, } \\
\text { and acute } \\
\text { illnesses, } \\
\text { such as } \\
\text { malaria and } \\
\text { jaundice, } \\
\text { than those } \\
\text { elderly who } \\
\text { are living } \\
\text { with their } \\
\text { family, even } \\
\text { after } \\
\text { controlling } \\
\text { for the } \\
\text { effects of a } \\
\text { number of } \\
\text { socioecono } \\
\text { mic, } \\
\text { demographi } \\
\text { c, } \\
\text { environment } \\
\text { al and } \\
\text { behavioural } \\
\text { confounders } \\
\text {. The } \\
\text { findings } \\
\text { have } \\
\text { important } \\
\text { programme } \\
\text { and policy } \\
\text { implications }\end{array}$ \\
\hline
\end{tabular}




\begin{tabular}{|c|c|c|c|c|c|c|}
\hline & & & & & $\begin{array}{l}\text { data were } \\
\text { obtained } \\
\text { from } \\
\text { faceto- } \\
\text { face } \\
\text { interviews } \\
\text { conducted } \\
\text { in the } \\
\text { respondent } \\
\text { s' homes. } \\
\text { The survey } \\
\text { was } \\
\text { conducted } \\
\text { using } \\
\text { an } \\
\text { interviewer } \\
\text { - } \\
\text { administere } \\
d \\
\text { questionnai } \\
\text { re in } 18 \\
\text { languages. } \\
\text { The analysis } \\
\text { presented } \\
\text { here is } \\
\text { based on } \\
39,694 \\
\text { persons } \\
\text { aged } 60 \\
\text { and above } \\
\text { living in the } \\
\text { sample } \\
\text { households } \\
\text { as a usual } \\
\text { resident. }\end{array}$ & $\begin{array}{l}\text { for countries } \\
\text { such as } \\
\text { India, which } \\
\text { has the } \\
\text { second } \\
\text { largest } \\
\text { elderly } \\
\text { population } \\
\text { in the world. } \\
\text { There is a } \\
\text { strong need } \\
\text { for the } \\
\text { implementat } \\
\text { ion of } \\
\text { specific } \\
\text { public } \\
\text { support } \\
\text { systems and } \\
\text { health care } \\
\text { strategies } \\
\text { focused on } \\
\text { the elderly } \\
\text { population } \\
\text { in general } \\
\text { and elderly } \\
\text { living alone } \\
\text { in particular. }\end{array}$ \\
\hline 2. $\begin{array}{l}2 \\
0 \\
1 \\
5\end{array}$ & $\begin{array}{l}\text { Wei-Jun, } \\
\text { J.Y. \& } \\
\text { Cheung, } \\
\text { A. K. L. }\end{array}$ & Asia & $\begin{array}{l}\text { Highlights } \\
\text { unique } \\
\text { features } \\
\text { found in } \\
\text { Asia, and } \\
\text { discusses } \\
\text { the } \\
\text { implications } \\
\text { of the } \\
\text { increase in } \\
\text { OPH in Asia } \\
\text { for }\end{array}$ & $\begin{array}{l}\text { Census } \\
\text { data are } \\
\text { used for an } \\
\text { internation } \\
\text { al } \\
\text { compariso } \\
\text { n of the } \\
\text { prevalence } \\
\text { of one- } \\
\text { person } \\
\text { households } \\
\text {. }\end{array}$ & $\begin{array}{l}\text { The ten } \\
\text { papers in } \\
\text { this } \\
\text { collection } \\
\text { examine } \\
\text { one-person } \\
\text { households } \\
\text { in } 15 \\
\text { countries in } \\
\text { East Asia } \\
\text { (China, } \\
\text { Japan, and }\end{array}$ & $\begin{array}{l}\text { The papers } \\
\text { reveal vast } \\
\text { heterogeneit } \\
\text { y across } \\
\text { regions and } \\
\text { within } \\
\text { nations. } \\
\text { While } \\
\text { widows } \\
\text { remains a } \\
\text { major group } \\
\text { of OPH, the }\end{array}$ \\
\hline
\end{tabular}




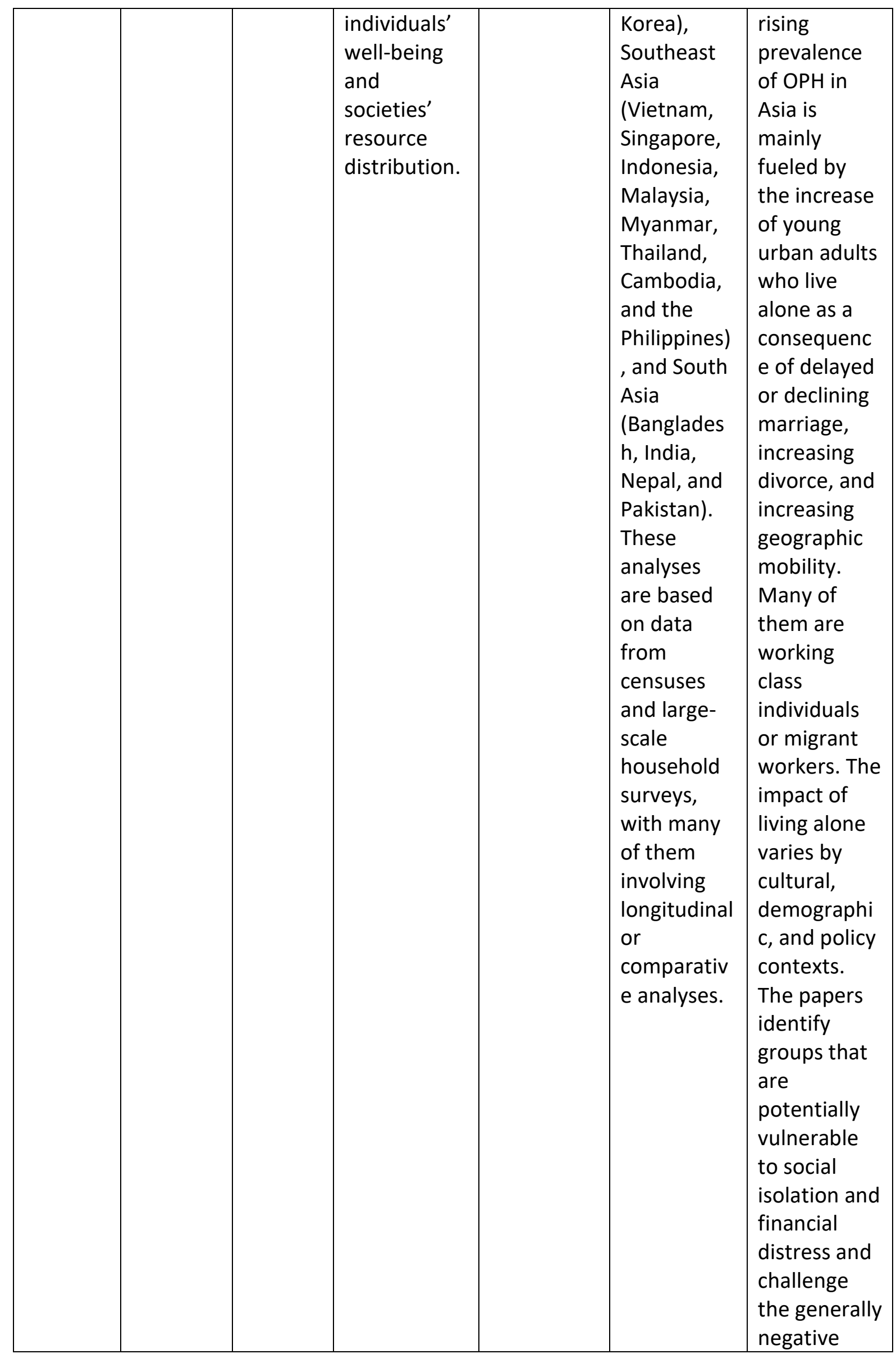




\begin{tabular}{|c|c|c|c|c|c|c|}
\hline & & & & & & $\begin{array}{l}\text { stereotypes } \\
\text { of the OPH } \\
\text { living } \\
\text { arrangement } \\
\text {. }\end{array}$ \\
\hline 3. $\begin{array}{l}2 \\
0 \\
1 \\
0\end{array}$ & $\begin{array}{l}\text { Ahmed } \\
\text { Mohame } \\
d \\
\text { Munsur, } \\
\text { Md } \\
\text { Ismail } \\
\text { Tareque, } \\
\text { \& K.M. } \\
\text { Mustafiz } \\
\text { ur } \\
\text { Rahman }\end{array}$ & $\begin{array}{l}\text { Banglad } \\
\text { esh }\end{array}$ & $\begin{array}{l}\text { The } \\
\text { objectives: } \\
\text { - to study } \\
\text { the extent of } \\
\text { socio- } \\
\text { economic } \\
\text { backdrops; } \\
\text { - to observe } \\
\text { the pattern } \\
\text { of living } \\
\text { arrangement } \\
\text { s and factors } \\
\text { affecting } \\
\text { living } \\
\text { arrangement } \\
\text { s; } \\
\text { - to observe } \\
\text { the current } \\
\text { health status } \\
\text { and factors } \\
\text { affecting } \\
\text { health } \\
\text { status; and } \\
\text { - to explore } \\
\text { the nature, } \\
\text { extent, } \\
\text { reasons of } \\
\text { elderly } \\
\text { abuse and } \\
\text { factors } \\
\text { responsible } \\
\text { for the } \\
\text { abuse of the } \\
\text { study } \\
\text { population } \\
\text { as well. }\end{array}$ & $\begin{array}{l}\text { Data } \\
\text { collected } \\
\text { from } 7 \\
\text { villages of } \\
\text { rural areas } \\
\text { under } \\
\text { Naogaon } \\
\text { district, } \\
\text { about } 36 \\
\text { km away } \\
\text { from } \\
\text { Rajshahi } \\
\text { divisional } \\
\text { town of } \\
\text { Bangladesh } \\
\text {. One } \\
\text { Thana } \\
\text { named, } \\
\text { Manda, } \\
\text { was } \\
\text { randomly } \\
\text { selected } \\
\text { from this } \\
\text { district. }\end{array}$ & $\begin{array}{l}\text { From all the } \\
\text { unions of } \\
\text { the } \\
\text { Thana, a } \\
\text { Union (9 } \\
\text { Number } \\
\text { Tintulia } \\
\text { Union } \\
\text { Parishad) } \\
\text { was } \\
\text { randomly } \\
\text { selected } \\
\text { and from } \\
\text { this } \\
\text { union } 7 \\
\text { villages } \\
\text { were } \\
\text { selected by } \\
\text { using } \\
\text { probability } \\
\text { proportiona } \\
\text { I to size } \\
\text { (PPS) } \\
\text { sampling. } \\
\text { In order to } \\
\text { perform the } \\
\text { above task, } \\
\text { first the } \\
\text { authors } \\
\text { made a } \\
\text { pilot survey } \\
\text { and } \\
\text { collected } \\
\text { voter list } \\
\text { from Union } \\
\text { Parishad } \\
\text { Office to } \\
\text { identify } \\
\text { truly the } \\
\text { aged and } \\
\text { then }\end{array}$ & $\begin{array}{l}\text { results show } \\
\text { that an } \\
\text { overwhelmi } \\
\text { ng majority } \\
\text { of the } \\
\text { elderly } \\
\text { women in } \\
\text { the age } \\
\text { group 60-69 } \\
\text { years who } \\
\text { are } \\
\text { widowed, } \\
\text { illiterate, } \\
\text { have no } \\
\text { education } \\
\text { and income, } \\
\text { economicall } \\
\text { y } \\
\text { dependent, } \\
\text { living with } \\
\text { married } \\
\text { children, } \\
\text { unhealthy, } \\
\text { suffer from } \\
\text { arthritis } \\
\text { related } \\
\text { illness and } \\
\text { are taking } \\
\text { treatment } \\
\text { from village } \\
\text { doctors. } \\
\text { Furthermore } \\
\text { the study } \\
\text { shows that, } \\
\text { nearly } 35 \\
\text { percent } \\
\text { elderly } \\
\text { women are } \\
\text { abused, } \\
\text { mostly } \\
\text { mentally } \\
\text { abused due }\end{array}$ \\
\hline
\end{tabular}




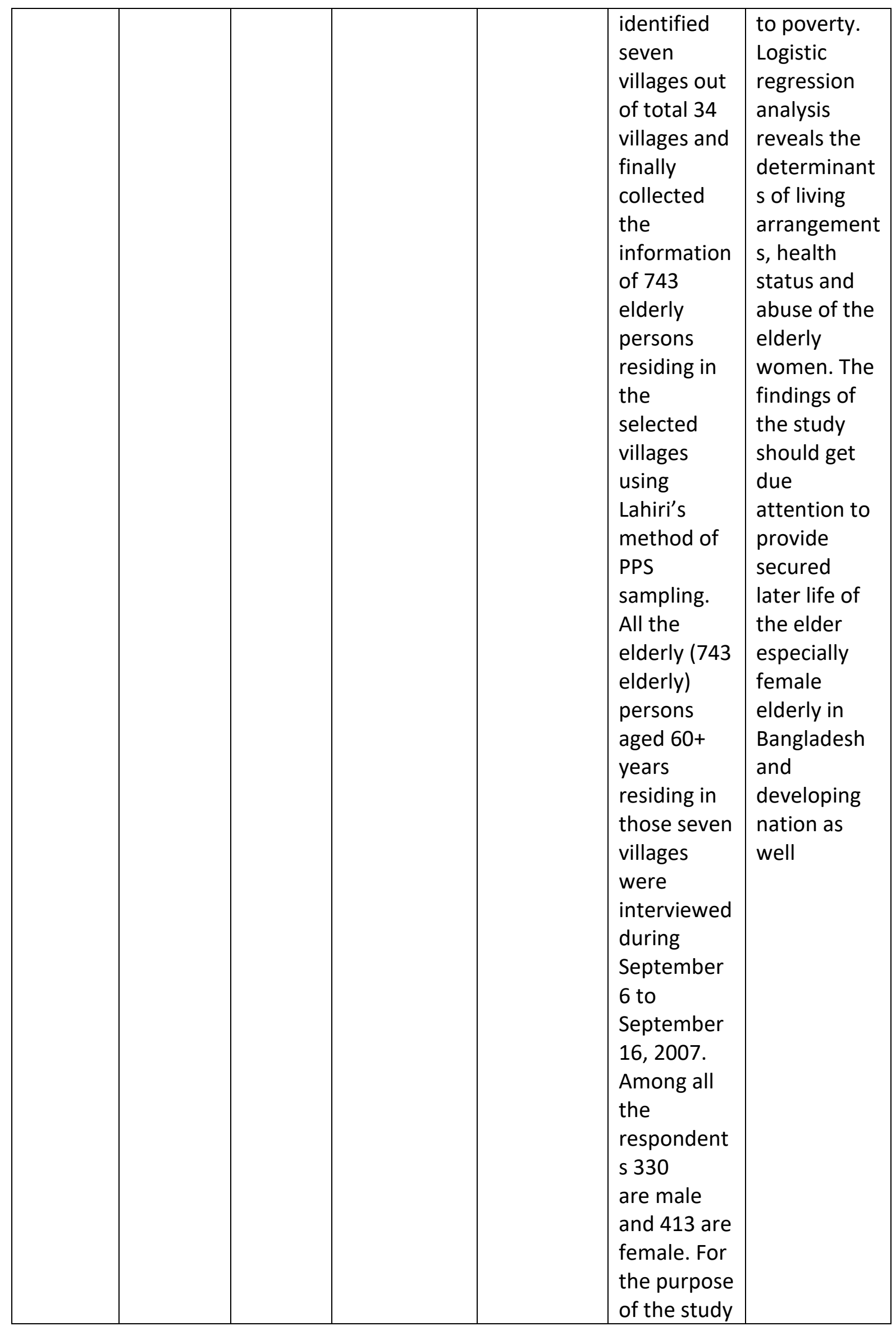




\begin{tabular}{|c|c|c|c|c|c|c|}
\hline & & & & & $\begin{array}{l}\text { we use only } \\
\text { female } \\
\text { respondent } \\
s^{\prime} \text { data. The } \\
\text { data were } \\
\text { edited, } \\
\text { compiled, } \\
\text { processed } \\
\text { and } \\
\text { analyzed by } \\
\text { using } \\
\text { SPSS } 15.0 \\
\text { program. }\end{array}$ & \\
\hline 4. $\begin{array}{l}2 \\
0 \\
1 \\
7\end{array}$ & $\begin{array}{l}\text { Nishanth } \\
\text { u, R. \& } \\
\text { Sampath, } \\
\text { K. S. }\end{array}$ & India & $\begin{array}{l}\text { The main } \\
\text { objective of } \\
\text { this the } \\
\text { descriptive } \\
\text { nature of } \\
\text { this study } \\
\text { was Socio } \\
\text { economic } \\
\text { condition } \\
\text { and Living } \\
\text { Arrangemen } \\
\text { ts of elders }\end{array}$ & $\begin{array}{l}\text { Elderly } \\
\text { residing in } \\
\text { Thiruchirap } \\
\text { alli West, } \\
\text { Tamil Nadu } \\
\text { with } \\
\text { sample of } \\
95 \text { elderly } \\
\text { aged } 60 \\
\text { years } \\
\text { above }\end{array}$ & $\begin{array}{l}\text { Interview } \\
\text { schedule } \\
\text { and } \\
\text { observation }\end{array}$ & $\begin{array}{l}\text { Results } \\
\text { shows that } \\
\text { both male } \\
\text { and female } \\
\text { elderly are } \\
\text { given } \\
\text { positive } \\
\text { opinion on } \\
\text { their living } \\
\text { arrangement } \\
\text {. Half of the } \\
\text { elderly live } \\
\text { with their } \\
\text { spouse and } \\
\text { enjoy good } \\
\text { infrastructur } \\
\text { e and } \\
\text { physical } \\
\text { facilities of } \\
\text { their house } \\
\text { like } \\
\text { electricity, } \\
\text { water, toilet, } \\
\text { ventilation } \\
\text { and lighting } \\
\text { facilities. } \\
\text { Majority } \\
\text { (86.31\%) } \\
\text { have } \\
\text { separate } \\
\text { living space. } \\
\text { The elderly } \\
\text { belongs to } \\
\text { nuclear }\end{array}$ \\
\hline
\end{tabular}




\begin{tabular}{|c|c|c|c|c|c|c|}
\hline & & & & & & $\begin{array}{l}\text { family are } \\
\text { well located } \\
\text { themselves } \\
\text { in regards to } \\
\text { the living } \\
\text { arrangement } \\
\text { s. }\end{array}$ \\
\hline 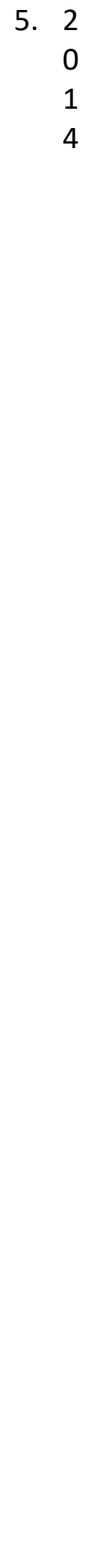 & $\begin{array}{l}\text { Tannisth } \\
\text { a, S., } \\
\text { Chen, F., } \\
\text { \& } \\
\text { Vannema } \\
\text { n. R. }\end{array}$ & India & $\begin{array}{l}\text { Investigating } \\
\text { the } \\
\text { association } \\
\text { between the } \\
\text { multigenerat } \\
\text { ional } \\
\text { household } \\
\text { context and } \\
\text { health of } \\
\text { older adults } \\
\text { in India, } \\
\text { taking into } \\
\text { account } \\
\text { potential } \\
\text { selection } \\
\text { effects. }\end{array}$ & $\begin{array}{l}\text { Data based } \\
\text { from the } \\
\text { India } \\
\text { Human } \\
\text { Developme } \\
\text { nt Survey } \\
\text { (2004-05), } \\
\text { a } \\
\text { nationally } \\
\text { representa } \\
\text { tive } \\
\text { multitopic } \\
\text { data set }\end{array}$ & $\begin{array}{l}\text { employed a } \\
\text { two-step } \\
\text { analytical } \\
\text { strategy- } \\
\text { logistic } \\
\text { regression } \\
\text { followed by } \\
\text { propensity } \\
\text { score } \\
\text { stratificatio } \\
\mathrm{n} \text { method- } \\
\text { to model } \\
\text { the effect } \\
\text { of } \\
\text { contrasting } \\
\text { living } \\
\text { arrangeme } \\
\text { nt types on } \\
\text { short-term } \\
\text { illness. }\end{array}$ & $\begin{array}{l}\text { older adults } \\
\text { living in } \\
\text { multigenerat } \\
\text { ional } \\
\text { households } \\
\text { have the } \\
\text { lowest levels } \\
\text { of short- } \\
\text { term illness. } \\
\text { Among } \\
\text { them, those } \\
\text { who live } \\
\text { with their } \\
\text { spouse, } \\
\text { adult } \\
\text { children, and } \\
\text { young } \\
\text { grandchildre } \\
\text { n experience } \\
\text { the highest } \\
\text { health gains. } \\
\text { Health } \\
\text { advantage } \\
\text { diminishes } \\
\text { when older } \\
\text { adults live } \\
\text { only with a } \\
\text { spouse and } \\
\text { adult } \\
\text { children, and } \\
\text { further } \\
\text { diminishes } \\
\text { when they } \\
\text { live only } \\
\text { with their } \\
\text { spouse. } \\
\text { Solitary } \\
\text { living is } \\
\text { associated } \\
\text { with the }\end{array}$ \\
\hline
\end{tabular}




\begin{tabular}{|c|c|c|c|c|c|c|}
\hline & & & & & & $\begin{array}{l}\text { highest } \\
\text { likelihood of } \\
\text { short-term } \\
\text { morbidity. } \\
\text { Good health } \\
\text { is also } \\
\text { shown to be } \\
\text { associated } \\
\text { with } \\
\text { household } \\
\text { wealth, } \\
\text { gender, } \\
\text { household } \\
\text { size, and } \\
\text { urban } \\
\text { residence. }\end{array}$ \\
\hline 6. $\begin{array}{l}2 \\
0 \\
1 \\
2\end{array}$ & $\begin{array}{l}\text { Hadi } \\
\text { Kooshiar, } \\
\text { Nurizan } \\
\text { Yahaya, } \\
\text { Tengku } \\
\text { Aizan } \\
\text { Hamid, } \\
\text { Asnarulk } \\
\text { hadi Abu } \\
\text { Samah, } \\
\text { \& } \\
\text { Vajiheh } \\
\text { Sedaghat } \\
\text { Jou }\end{array}$ & $\begin{array}{l}\text { Peninsu } \\
\text { la } \\
\text { Malaysi } \\
\text { a }\end{array}$ & $\begin{array}{l}\text { Cross- } \\
\text { sectional } \\
\text { and } \\
\text { correlational } \\
\text { survey } \\
\text { examines } \\
\text { the } \\
\text { association } \\
\text { between } \\
\text { different } \\
\text { types of } \\
\text { living } \\
\text { arrangement } \\
\text { s and life } \\
\text { satisfaction } \\
\text { in older } \\
\text { Malaysians, } \\
\text { while taking } \\
\text { into account } \\
\text { the } \\
\text { mediating } \\
\text { effects of } \\
\text { social } \\
\text { support } \\
\text { function. }\end{array}$ & $\begin{array}{l}\text { Study used } \\
\text { a } \\
\text { secondary } \\
\text { database. } \\
\text { The } \\
\text { original } \\
\text { database } \\
\text { was } \\
\text { collected } \\
\text { using a } \\
\text { cross- } \\
\text { sectional } \\
\text { and co- } \\
\text { relational } \\
\text { survey } \\
\text { titled } \\
\text { “Patterns } \\
\text { of Social } \\
\text { Relationshi } \\
\text { ps and } \\
\text { Psychologi } \\
\text { cal Well- } \\
\text { being } \\
\text { among } \\
\text { Older } \\
\text { People in } \\
\text { Peninsular } \\
\text { Malaysia } \\
\text { (PSRPWO)' } \\
\text { ' For }\end{array}$ & $\begin{array}{l}\text { The survey } \\
\text { divided } \\
\text { Peninsular } \\
\text { Malaysia } \\
\text { into four } \\
\text { zones to } \\
\text { determine } \\
\text { the } \\
\text { locations } \\
\text { of the } \\
\text { study. } \\
\text { Samples } \\
\text { consisted of } \\
\text { Malaysians } \\
60 \text { years } \\
\text { and older } \\
\text { who lived in } \\
\text { the } \\
\text { community. } \\
\text { The total } \\
\text { number of } \\
\text { respondent } \\
\text { s } \\
\text { included in } \\
\text { this study } \\
\text { was } 1880 \\
\text { older } \\
\text { adults. } \\
\text { Respondent } \\
\text { s were }\end{array}$ & $\begin{array}{l}\text { The result } \\
\text { shows living } \\
\text { with } \\
\text { children as } \\
\text { the } \\
\text { commonest } \\
\text { type of living } \\
\text { arrangement } \\
\text { for older } \\
\text { adults in } \\
\text { peninsular } \\
\text { Malaysia. } \\
\text { Compared } \\
\text { to living } \\
\text { alone, living } \\
\text { only with a } \\
\text { spouse } \\
\text { especially } \\
\text { and then co- } \\
\text { residency } \\
\text { with } \\
\text { children } \\
\text { were } \\
\text { both } \\
\text { associated } \\
\text { with better } \\
\text { life } \\
\text { satisfaction } \\
\text { and social } \\
\text { support } \\
\text { function. }\end{array}$ \\
\hline
\end{tabular}




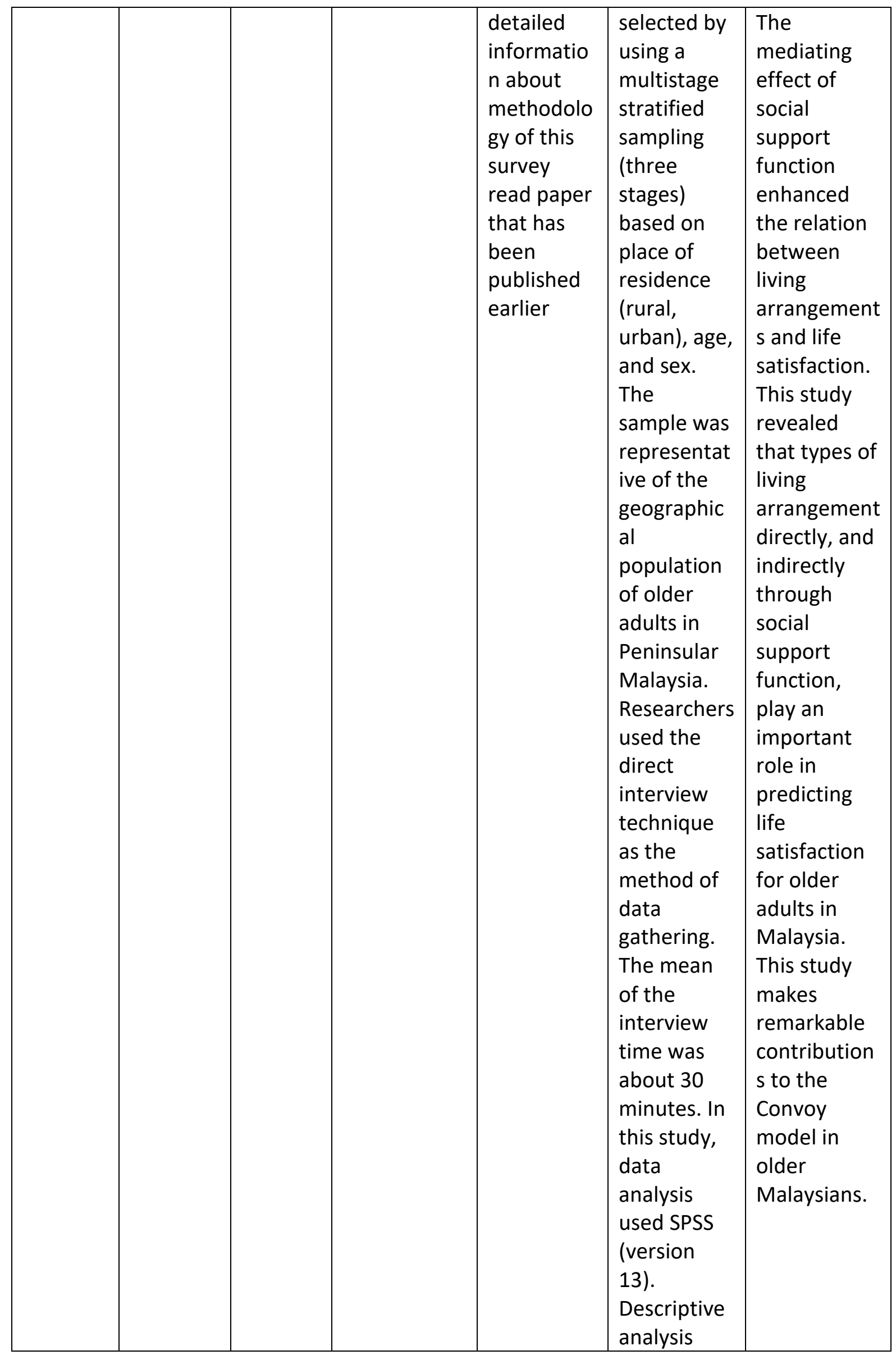




\begin{tabular}{|c|c|c|c|c|c|c|}
\hline & & & & & $\begin{array}{l}\text { was } \\
\text { conducted } \\
\text { for socio- } \\
\text { demographi } \\
\text { c variables, } \\
\text { Philadelphi } \\
\text { a Geriatric } \\
\text { Center } \\
\text { Morale } \\
\text { Scale } \\
\text { (PGCMS), } \\
\text { and } \\
\text { Medical } \\
\text { Outcomes } \\
\text { Study Social } \\
\text { Support } \\
\text { Survey } \\
\text { (MOS-SSS) } \\
\text { scales. The } \\
\text { respondent } \\
\text { s' mean } \\
\text { scores on } \\
\text { life } \\
\text { satisfaction } \\
\text { and social } \\
\text { support } \\
\text { across living } \\
\text { arrangeme } \\
\text { nts were } \\
\text { also } \\
\text { compared } \\
\text { using one- } \\
\text { way } \\
\text { analysis of } \\
\text { variance } \\
\text { (ANOVA). }\end{array}$ & \\
\hline 7. $\begin{array}{l}2 \\
0 \\
1 \\
3\end{array}$ & $\begin{array}{l}\text { Abalos, J. } \\
\text { B. \& } \\
\text { Barona, } \\
\text { M. F. C. } \\
\text { T. }\end{array}$ & $\begin{array}{l}\text { Southea } \\
\text { st Asia }\end{array}$ & $\begin{array}{l}\text { This study } \\
\text { aims to: 1) } \\
\text { compare the } \\
\text { trends and } \\
\text { patterns of } \\
\text { living } \\
\text { arrangement } \\
\text { s of the } \\
\text { older } \\
\text { persons in } \\
\text { Southeast }\end{array}$ & $\begin{array}{l}\text { Census } \\
\text { data for } \\
\text { Cambodia, } \\
\text { Malaysia, } \\
\text { Philippines, } \\
\text { Thailand } \\
\text { and } \\
\text { Vietnam } \\
\text { from } 1970 \\
\text { to 2009, } \\
\text { provided }\end{array}$ & $\begin{array}{l}\text { Defined } \\
\text { older } \\
\text { persons as } \\
\text { those ages } \\
60 \text { years } \\
\text { and over. } \\
\text { Living } \\
\text { arrangeme } \\
\text { nt was } \\
\text { categorised } \\
\text { into: (1) }\end{array}$ & $\begin{array}{l}\text { Living in an } \\
\text { extended } \\
\text { household } \\
\text { remains the } \\
\text { most } \\
\text { predominan } \\
\text { t type of } \\
\text { living } \\
\text { arrangement } \\
\text { among older } \\
\text { persons in }\end{array}$ \\
\hline
\end{tabular}




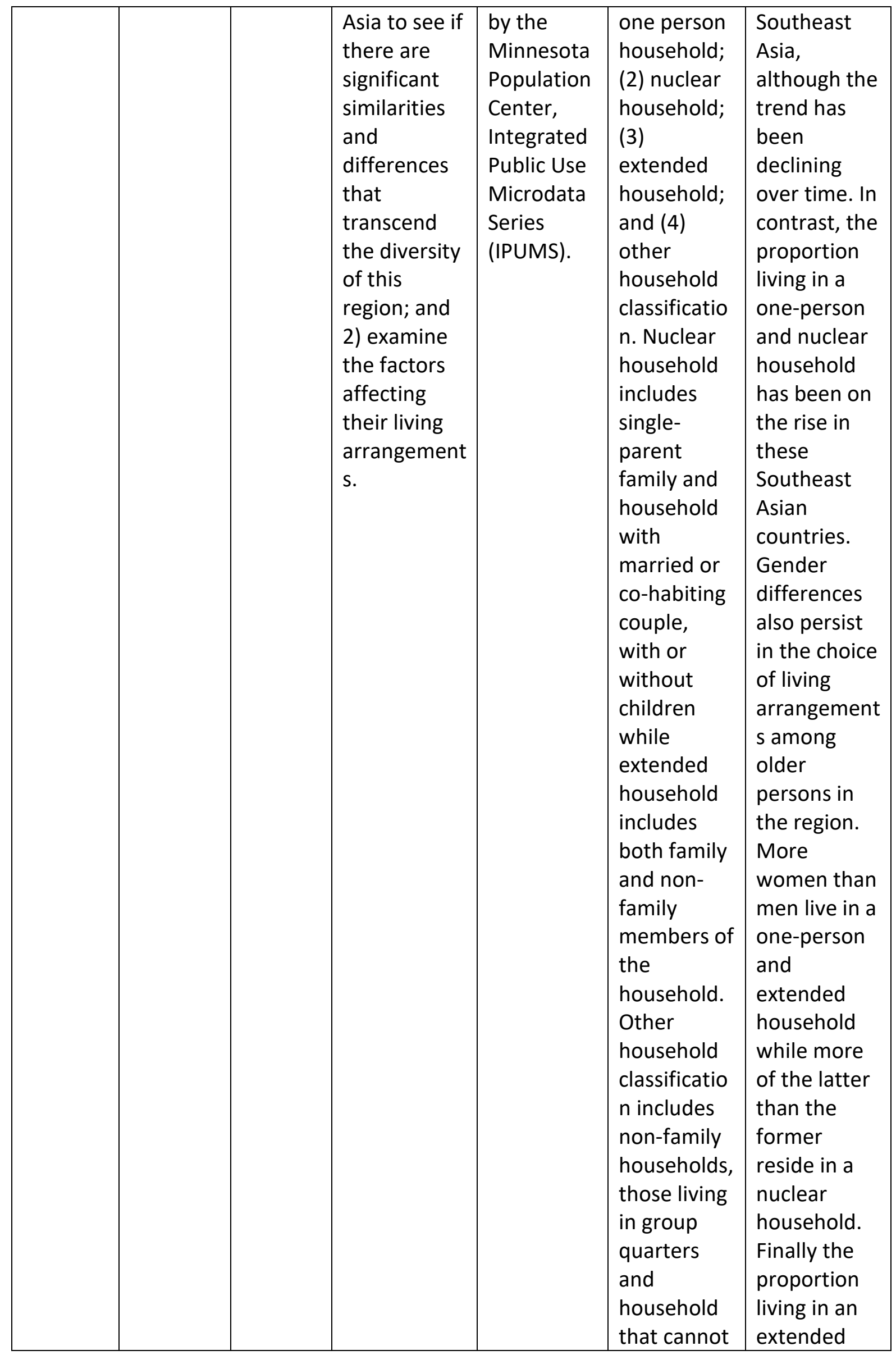




\begin{tabular}{|c|c|c|c|c|c|c|}
\hline & & & & & $\begin{array}{l}\text { be } \\
\text { classified. } \\
\text { We will } \\
\text { focus on } \\
\text { the } \\
\text { proportion } \\
\text { living in an } \\
\text { extended } \\
\text { household } \\
\text { and present } \\
\text { its } \\
\text { differentials } \\
\text { across age } \\
\text { groups, } \\
\text { level of } \\
\text { education, } \\
\text { marital } \\
\text { status, } \\
\text { employmen } \\
\text { t status and } \\
\text { place of } \\
\text { residence. } \\
\text { Given the } \\
\text { gender } \\
\text { differences } \\
\text { in living } \\
\text { arrangeme } \\
\text { nts of older } \\
\text { persons } \\
\text { separate } \\
\text { analyses } \\
\text { are } \\
\text { conducted } \\
\text { for men } \\
\text { and } \\
\text { women. }\end{array}$ & $\begin{array}{l}\text { household } \\
\text { differs by } \\
\text { age, marital } \\
\text { status, level } \\
\text { of education } \\
\text { and place of } \\
\text { residence. }\end{array}$ \\
\hline $\begin{array}{l}\text { 8. } 2 \\
0 \\
1 \\
7\end{array}$ & $\begin{array}{l}\text { Jiehua, L. } \\
\text { \& Yun, Z. }\end{array}$ & China & $\begin{array}{l}\text { Examine the } \\
\text { changes and } \\
\text { consequenc } \\
\text { es of the } \\
\text { patterns of } \\
\text { Chinese } \\
\text { elderly } \\
\text { population's } \\
\text { living } \\
\text { arrangement } \\
\text { s. It contains }\end{array}$ & $\begin{array}{l}\text { Based on } \\
\text { the } \\
\text { analysis of } \\
\text { the } \\
\text { population } \\
\text { census } \\
\text { data in } \\
2000 \text { and } \\
2010 \text {, }\end{array}$ & $\begin{array}{l}\text { Based on } \\
\text { the analysis } \\
\text { of the } \\
\text { population } \\
\text { census data } \\
\text { in } 2000 \text { and } \\
2010 \text {, the } \\
\text { authors } \\
\text { examined } \\
\text { the changes } \\
\text { and trends }\end{array}$ & $\begin{array}{l}\text { First, the } \\
\text { proportion } \\
\text { of the } \\
\text { elderly } \\
\text { people living } \\
\text { with } \\
\text { children has } \\
\text { been } \\
\text { decreasing. } \\
\text { Second, the } \\
\text { proportions }\end{array}$ \\
\hline
\end{tabular}




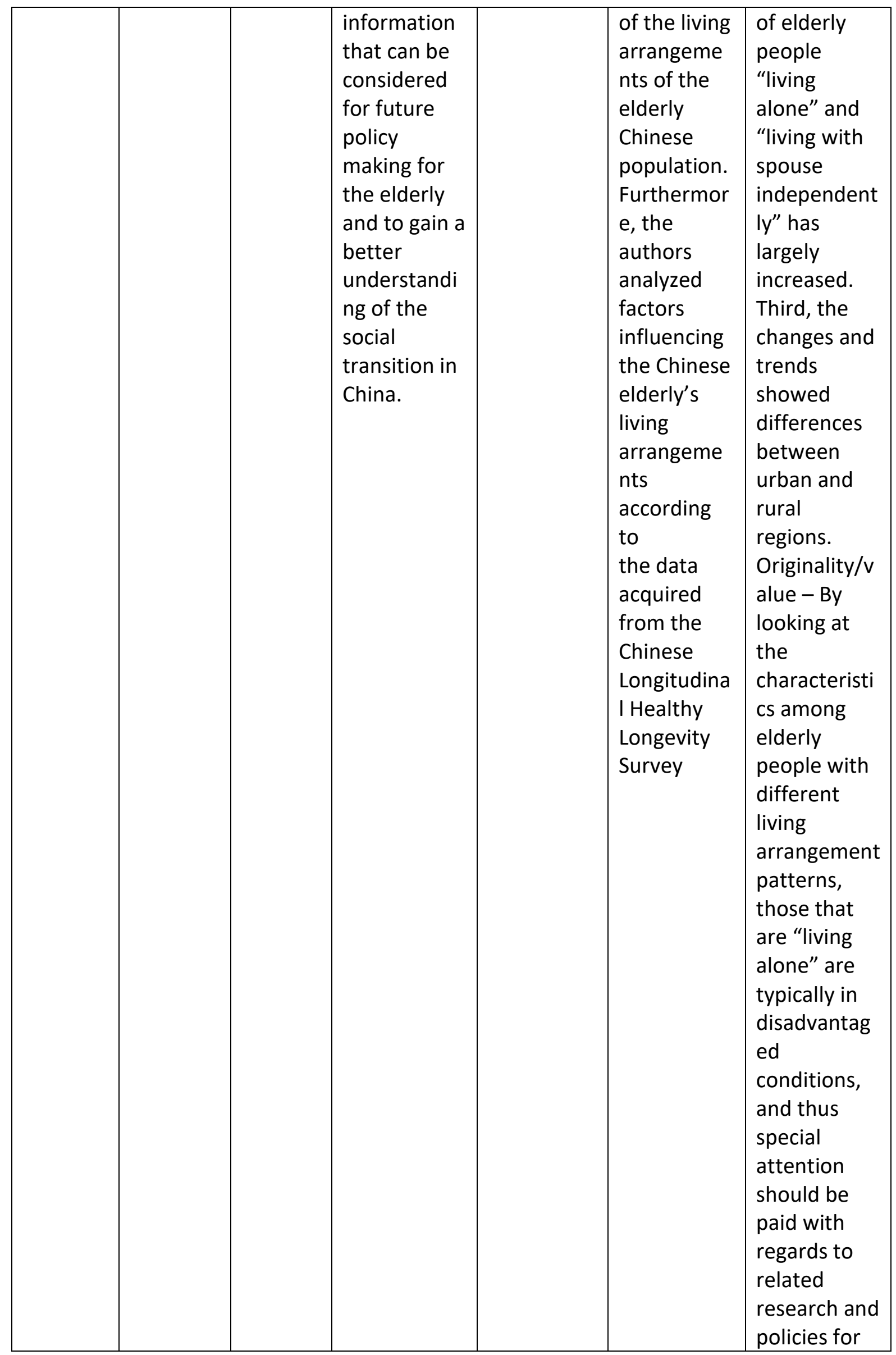




\begin{tabular}{|c|c|c|c|c|c|c|}
\hline & & & & & & $\begin{array}{l}\text { the elderly } \\
\text { who are } \\
\text { "living } \\
\text { alone." }\end{array}$ \\
\hline 9. $\begin{array}{l}2 \\
0 \\
1 \\
3\end{array}$ & $\begin{array}{l}\text { Golandaj } \\
\text {, J. A., } \\
\text { Goli, S. \& } \\
\text { Das, K. C. }\end{array}$ & India & $\begin{array}{l}\text { The purpose } \\
\text { of this paper } \\
\text { is to } \\
\text { investigate } \\
\text { the pattern } \\
\text { of living } \\
\text { arrangement } \\
\text { s among the } \\
\text { older } \\
\text { population } \\
\text { and } \\
\text { perception } \\
\text { about old } \\
\text { age support } \\
\text { in the Indian } \\
\text { adult } \\
\text { population. }\end{array}$ & $\begin{array}{l}\text { used India } \\
\text { Human } \\
\text { Developme } \\
\text { nt Survey } \\
\text { (IHDS), } \\
\text { 2004-2005 } \\
\text { data for } \\
\text { empirical } \\
\text { analyses. }\end{array}$ & $\begin{array}{l}\text { Bivariate } \\
\text { and } \\
\text { multivariate } \\
\text { models are } \\
\text { used as } \\
\text { statistical } \\
\text { analyses for } \\
\text { this study. } \\
\text { This study is } \\
\text { an } \\
\text { evidence- } \\
\text { based } \\
\text { interpretati } \\
\text { on of living } \\
\text { arrangeme } \\
\text { nts among } \\
\text { older } \\
\text { persons and } \\
\text { perception } \\
\text { about } \\
\text { future living } \\
\text { arrangeme } \\
\text { nt and } \\
\text { financial } \\
\text { assistance } \\
\text { among } \\
\text { current } \\
\text { adult } \\
\text { people. }\end{array}$ & $\begin{array}{l}\text { It was found } \\
\text { that } 17 \\
\text { percent of } \\
\text { older } \\
\text { population } \\
\text { lived with } \\
\text { their spouse } \\
\text { only; only } 2 \\
\text { percent lived } \\
\text { singly, and } \\
\text { the rest of } \\
85 \text { percent } \\
\text { elderly were } \\
\text { living in co- } \\
\text { residence } \\
\text { with } \\
\text { children. } \\
\text { A majority of } \\
\text { women } \\
\text { respondents } \\
\text { are } \\
\text { expecting } \\
\text { their sons to } \\
\text { live with } \\
\text { them, to } \\
\text { take care } \\
\text { and provide } \\
\text { financial and } \\
\text { emotional } \\
\text { support in } \\
\text { their old } \\
\text { age. This } \\
\text { indicates } \\
\text { that the } \\
\text { family will } \\
\text { continue to } \\
\text { be a } \\
\text { significant } \\
\text { social } \\
\text { institution } \\
\text { for the care } \\
\text { and support } \\
\text { for the older }\end{array}$ \\
\hline
\end{tabular}




\begin{tabular}{|c|c|c|c|c|c|c|}
\hline & & & & & & $\begin{array}{l}\text { population } \\
\text { in India. } \\
\text { Originality/v } \\
\text { alue - This } \\
\text { study is the } \\
\text { first of its } \\
\text { kind, which, } \\
\text { in addition, } \\
\text { to living } \\
\text { arrangement } \\
\text { patterns of } \\
\text { the older } \\
\text { population, } \\
\text { provides } \\
\text { some insight } \\
\text { about the } \\
\text { expectations } \\
\text { of the } \\
\text { current } \\
\text { adult } \\
\text { generation } \\
\text { about living } \\
\text { and financial } \\
\text { preferences } \\
\text { in old age. }\end{array}$ \\
\hline $\begin{array}{r}10.2 \\
0 \\
1 \\
2\end{array}$ & $\begin{array}{l}\text { Racelis, } \\
\text { R. H., } \\
\text { Abrigo, } \\
\text { M. R. M., } \\
\text { \& Salas, } \\
\text { J. M. I. S. }\end{array}$ & $\begin{array}{l}\text { Philippi } \\
\text { nes }\end{array}$ & $\begin{array}{l}\text { Explores } \\
\text { how elderly } \\
\text { labor } \\
\text { income can } \\
\text { be expanded } \\
\text { as a } \\
\text { financing } \\
\text { source for } \\
\text { elderly } \\
\text { consumptio } \\
\text { n in the } \\
\text { future } \\
\text { through } \\
\text { increase in } \\
\text { elderly work } \\
\text { activity. It } \\
\text { examines } \\
\text { elderly living } \\
\text { arrangement } \\
\text { s and other } \\
\text { factors that } \\
\text { may }\end{array}$ & $\begin{array}{l}\text { The } \\
\text { prospects } \\
\text { of } \\
\text { increasing } \\
\text { elderly } \\
\text { work } \\
\text { activity in } \\
\text { the } \\
\text { future is } \\
\text { assessed } \\
\text { based on } \\
\text { past and } \\
\text { possible } \\
\text { future } \\
\text { trends in } \\
\text { the } \\
\text { following } \\
\text { three } \\
\text { factors, } \\
\text { among } \\
\text { many } \\
\text { others: }\end{array}$ & $\begin{array}{l}\text { Alternative } \\
\text { scenarios of } \\
\text { increases in } \\
\text { elderly } \\
\text { labor force } \\
\text { size (based } \\
\text { on assumed } \\
\text { changes in } \\
\text { the factors) } \\
\text { were used } \\
\text { in } \\
\text { simulations } \\
\text { and results } \\
\text { show that } \\
\text { the higher } \\
\text { the } \\
\text { increase in } \\
\text { labor force } \\
\text { size (1) the } \\
\text { higher the } \\
\text { increase in } \\
\text { aggregate }\end{array}$ & $\begin{array}{l}\text { Elderly } \\
\text { working in } \\
\text { older age } \\
\text { shows that } \\
\text { the } \\
\text { percentage } \\
\text { of working } \\
\text { elderly will } \\
\text { decline in } \\
\text { accordance } \\
\text { to their age, } \\
\text { for example } \\
\text { the study } \\
\text { shows that } \\
\text { age group of } \\
58-64 \text { has } 65 \\
\text { percent } \\
\text { while } 80 \\
\text { years above } \\
\text { has only } 16 \\
\text { percent and } \\
\text { majority of }\end{array}$ \\
\hline
\end{tabular}




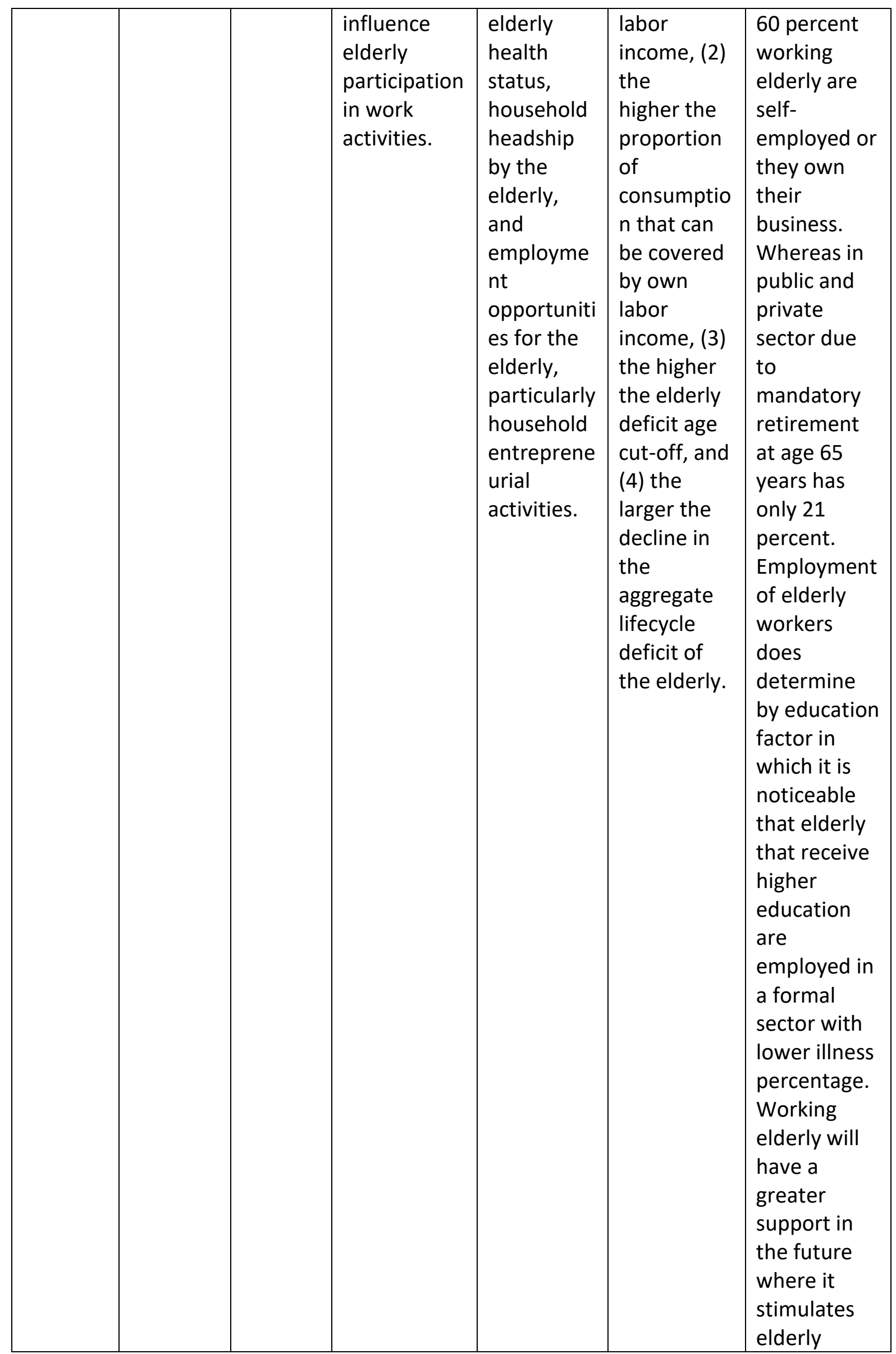


INTERNATIONAL JOURNAL OF ACADEMIC RESEARCH IN BUSINESS AND SOCIAL SCIENCES Vol. 11, No. 5, 2021, E-ISSN: 2222-6990 @ 2021 HRMARS

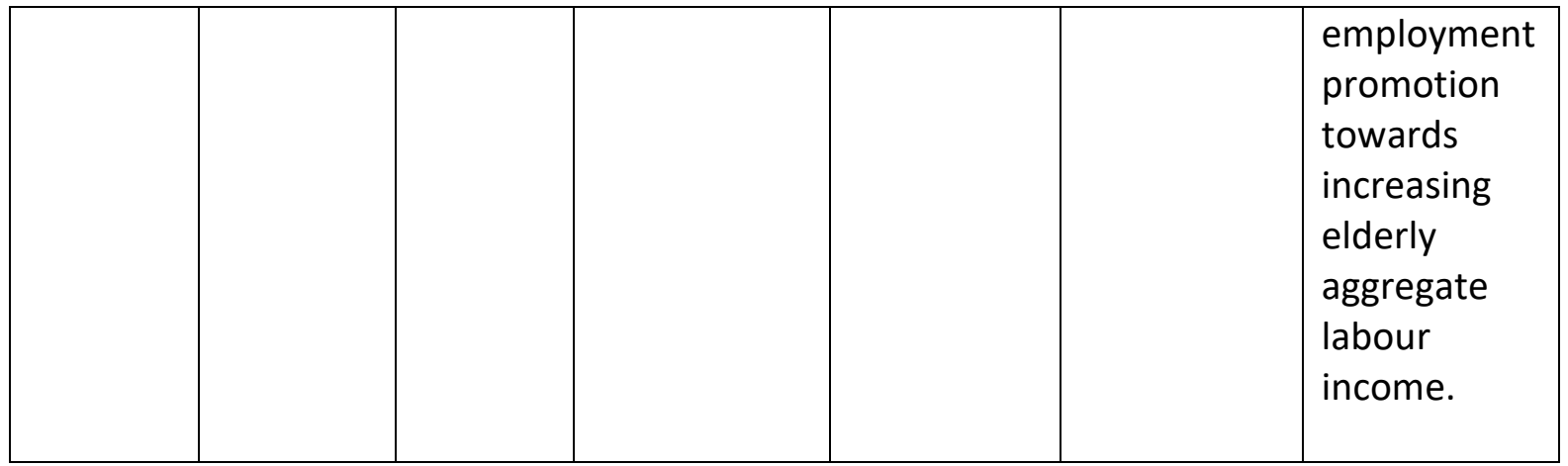

